Животноводство и кормопроизводство 2021 / Animal Husbandry and Fodder Production 2021;104(4) 32

БИОЭЛЕМЕНТОЛОГИЯ В ЖИВОТНОВОДСТВЕ И РАСТЕНИЕВОДСТВЕ/ BIOELEMENTOLOGY IN ANIMAL HUSBANDRY AND CROP PRODUCTION

Животноводство и кормопроизводство. 2021. Т. 104, № 4. С. 32-38.

Animal Husbandry and Fodder Production. 2021. Vol. 104, no 4. P. 32-38.

Original article

BIOELEMENTOLOGY IN ANIMAL HUSBANDRY AND CROP PRODUCTION

UDC 636.085:577.17

doi:10.33284/2658-3135-104-4-32

\title{
Introduction of Mineral TS in a normal fertilization protocol and the influence on the fertility and levels of some bio-elements in cattle
}

\author{
George V Goilean ${ }^{1}$, Romeo T Cristina ${ }^{2}$, Alexandru O Doma ${ }^{3}$, Eugenia Dumitrescu ${ }^{4}$, \\ Alexandru E Mizeranschi ${ }^{5}$, Răzvan F Moruzi ${ }^{6}$, Diana M Degi ${ }^{7}$, Sergiu A Orăsan ${ }^{8}$, \\ Radu I Neamt ${ }^{9}$, Florin Muselin ${ }^{10,11}$ \\ $\mathbf{1 , 2 , 3 , 4 , 6 , 7 , 8 , 1 0}$ Banat's University of Agricultural Sciences and Veterinary Medicine "King Michel I of Romania" \\ from Timisoara, Timisoara, Romania \\ ${ }^{11}$ Working Group for Xenobiochemistry, Romanian Academy-Branch Timisoara, Timisoara, Romania \\ ${ }^{5,9}$ Research and Development Station for Bovine - Arad, Arad, Romania \\ 2 https://orcid.org/0000-0002-5420-1516 \\ ${ }^{3} \mathrm{https}: / /$ orcid.org/0000-0001-5252-6969 \\ ${ }^{4}$ https://orcid.org/0000-0002-8346-6230 \\ ${ }^{5}$ https://orcid.org/0000-0002-1168-6285 \\ ${ }^{6} \mathrm{https}: / /$ orcid.org/0000-0001-7769-6358 \\ ${ }^{7} \mathrm{https}: / /$ orcid.org/0000-0002-6975-4914 \\ ${ }^{8}$ https://orcid.org/0000-0002-6704-0459 \\ ${ }^{9} \mathrm{https}$ ://orcid.org/0000-0002-5812-8870 \\ 10,11 florin.muselin@gmail.com, https://orcid.org/0000-0003-2907-4233
}

Abstract. The paper presents data regarding the status of some important bioelements for the bovine fertility when a mineral supplement was added to a normal fertility protocol in cattle and the influence of this upon the fertility percentage. The study was made on sixty Romanian Spotted cattle 18-19 months old divided randomly in four groups as follows: $\mathrm{C}-$ Control, and three experimental groups E1 - E3, that received a normal fertility protocul with Ovarelin $(\mathrm{GnRh})$ in day 1 and day 10, Enzaprost (PGF2 $\alpha)$ in day 7. E1 received in plus Sel-E-Vit (Selenium+Vit.E), E2 received Mineral TS and E3 Sel-E-Vit + Mineral TS. The cattles were blind artificial inseminated in day 11 and gestation diagnosis was performen by ultrasound method in day 55 and the percentage of fertility was analyzed. Blood samples were collected in day 0 and day 12 for trace elements analisys by AAS flame and furnace method. Were measured the serum levels of iron $(\mathrm{Fe})$, manganese $(\mathrm{Mn})$, copper $(\mathrm{Cu})$, zinc $(\mathrm{Zn})$, and selenium $(\mathrm{Se})$. In all experimental groups in day 0 were not significant $(\mathrm{P} \geq 0.05)$ differences regarding the studied trace elements. In day 12 we observed a significant increase of Se and Fe in E2 and E3 groups and of $\mathrm{Cu}$ in E2 group comparative to controol. On the other hand was recorded a significant decrease of $\mathrm{Zn}$ and not significant decrease of $\mathrm{Mn}$ in all experimental groups comparative to control. The conception rate and percentage of fertility was higher in E1 followed by E2 and E3 groups comparative to control. We can conclude that the introduction of a mineral supplement, in our case Mineral TS, could increase the the conception rate and fertility percentage in cattle.

Keywords: cattle, cows, feeding, bio-elements, supplements, minerals

Acknowledgments: special thanks for their help and support to Mr. David Chirilă and Mrs. Mihaela Scurtu from AMS 2000 Trading Impex SRL, Jebel, Romania.

For citation: Goilean GV, Cristina RT, Doma AO, Dumitrescu E, Mizeranschi AE, Moruzi RF Degi DM, Orăsan SA, Neamt RI, Muselin F. Introduction of Mineral TS in a normal fertilization protocol and the influence on the fertility and levels of some bio-elements in cattle. Animal Husbandry and Fodder Production. 2021;104(4):32-38. https://doi.org/10.33284/2658-3135-104-4-32

\section{Introduction.}

The essential bioelements are defined as the elements whose dietary deficiency can affect adversely and consistently the biological functions from optimal and change of this could be prevented or reestablished by physiological amounts of these elements (Nielsen FH, 2003).

(C) Goilean GV, Cristina RT, Doma AO, Dumitrescu E, Mizeranschi AE, Moruzi RF, Degi DM, Orăsan SA,

Neamț RI, Muselin F., 2021 
Животноводство и кормопроизводство 2021 / Animal Husbandry and Fodder Production 2021;104(4)

БИОЭЛЕМЕНТОЛОГИЯ В ЖИВОТНОВОДСТВЕ И РАСТЕНИЕВОДСТВЕ/

BIOELEMENTOLOGY IN ANIMAL HUSBANDRY AND CROP PRODUCTION

Supplementation with extra vitamins and minerals to the diet has often been proposed as a "golden bullet" solution to reduce declines in cow fertility by various commercial interests, while requirements for optimal reproductive proficiency in modern dairy cattle deserve careful re-evaluation based on welldesigned scientific research (Hurley WL and Doane RM, 1989; Crowe MA et al., 2018).

Trace elements deficiency can have profound effects on the reproductive performance of cattle. Previously has been reported many reproductive effects associated with clinical copper deficiency and high dietary molybdenum intakes such as: infertility, decreased conception rate, anestrus and delayed onset of puberty in cattle (Mackenzie AM et al., 2001). Trace elements like copper, zinc and selenium seems to be deficient in ruminants and could impair the production and reproduction parameters of these species (McDowell LR and Arthington JD, 2005; León-Cruz M et al., 2020).

The aim of the presented study was to emphasize the influence of Mineral TS supplement on status of some bioelements in cattles that received it and to asses if this supplementation will influence the fertility percentage in condition of a normal fertility protocol.

\section{Materials and methods.}

The study was carried out on a number of sixty Romanian Spotted cattles, kept in free housing throughout the year. The age of the cattles was $18.37 \pm 0.27$ months, with amplitudes ranging from a minimum of 18 months to a maximum of 19 months. The number can be considered strongly homogeneous, the coefficient of variability being $1.48 \%$. At the time of inclusion in the study, the body condition of the cattles was assessed in terms of body weight. The average value was set at the threshold of $396.18 \pm 9.06 \mathrm{~kg}$ with a minimum limit of $382 \mathrm{~kg}$ and a maximum of $413 \mathrm{~kg}$, the variability reached the threshold of $2.28 \%$, data being extremely comparable as a value that characterizes the herd.

The cattles were housed in a common paddock, ensuring an area of 8 square meters/head and free access to feed and water sources. The feed allowed the accumulation of an average daily increase between 0.5-0.62 $\mathrm{kg}$, being implemented a dynamic feeding strategy that allowed maintaining an optimal body condition in relation to the age of the animals. The feed provided to the cattles consist in $3 \mathrm{~kg}$ of concentrates, $7 \mathrm{~kg}$ of alfalfa hay and $17 \mathrm{~kg}$ of corn silage. The feeding was twice a day, in an individual front of $75 \mathrm{~cm} /$ head. The study was carried out within the zootechnical biobase of SCDCB Arad, Romania. The inclusion of the animals in the study as well as the experimental procedures were approved in the Scientific Council of SCDCB Arad, Romania, the Decision no. 62/15.11.2020. In addition, all procedures in this study fully comply with the EU Directive on Animal Experiments (Directive 2010/63/ $\mathrm{EU})$. The cattles were randomly distributed in four experimental groups $(\mathrm{n}=15)$ as follows: $\mathrm{C}-$ Control and three experimental groups E1-E3 respecting the experimental protocol from table 1.

Table 1. Time table for the experimental protocol

\begin{tabular}{|c|c|c|c|c|}
\hline \multirow[t]{2}{*}{ Time } & \multicolumn{4}{|c|}{ Experimental groups } \\
\hline & $\mathbf{C}$ & E1 & E2 & $\mathbf{E 3}$ \\
\hline Day 0 & Blood sampling & Blood sampling & Blood sampling & Blood sampling \\
\hline Day 1 & $\begin{array}{l}\text { Ovarelin } 2 \mathrm{ml} \text { i.m. } \\
+ \text { physiologic saline } \\
10 \mathrm{ml} \text { i.m. }\end{array}$ & $\begin{array}{l}\text { Ovarelin } 2 \mathrm{ml} \mathrm{i.m.} \\
+ \text { Sel-E-Vit } 10 \mathrm{ml} \\
\text { i.m. }\end{array}$ & $\begin{array}{l}\text { Ovarelin } 2 \mathrm{ml} \text { i.m. } \\
+ \text { orally Mineral } \\
\text { TS } 15 \mathrm{ml} / 100 \mathrm{~kg} \\
\text { diluted in } 600 \mathrm{ml} \\
\mathrm{H} 2 \mathrm{O}\end{array}$ & $\begin{array}{l}\text { Ovarelin } 2 \mathrm{ml} \text { i.m. } \\
+ \text { Sel-E-Vit } 10 \mathrm{ml} \text { i.m. } \\
\text { and orally Mineral TS } \\
15 \mathrm{ml} / 100 \mathrm{~kg} \text { diluted in } \\
600 \mathrm{ml} \mathrm{H} 2 \mathrm{O}\end{array}$ \\
\hline Day 2 & $\begin{array}{l}\text { physiologic saline } 5 \\
\text { ml i.m. }\end{array}$ & Sel-E-Vit $5 \mathrm{ml}$ i.m. & $\begin{array}{l}\text { orally Mineral TS } \\
15 \mathrm{ml} / 100 \mathrm{~kg} \text { diluted } \\
\text { in } 600 \mathrm{ml} \mathrm{H} 2 \mathrm{O}\end{array}$ & $\begin{array}{l}\text { Sel-E-Vit } 10 \mathrm{ml} \text { i.m. and } \\
\text { orally Mineral TS } \\
15 \mathrm{ml} / 100 \mathrm{~kg} \text { diluted in } \\
600 \mathrm{ml} \mathrm{H} 2 \mathrm{O}\end{array}$ \\
\hline Day 3 & $\begin{array}{l}\text { physiologic saline } 5 \\
\text { ml i.m. }\end{array}$ & Sel-E-Vit $5 \mathrm{ml}$ i.m. & $\begin{array}{l}\text { orally Mineral TS } \\
15 \mathrm{ml} / 100 \mathrm{~kg} \text { diluted } \\
\text { in } 600 \mathrm{ml} \mathrm{H} 2 \mathrm{O}\end{array}$ & $\begin{array}{l}\text { Sel-E-Vit } 10 \mathrm{ml} \text { i.m. and } \\
\text { orally Mineral TS } \\
15 \mathrm{ml} / 100 \mathrm{~kg} \text { diluted in } \\
600 \mathrm{ml} \mathrm{H} 2 \mathrm{O}\end{array}$ \\
\hline Day 7 & Enzaprost T $5 \mathrm{ml}$ i.m. & Enzaprost T $5 \mathrm{ml}$ i.m. & Enzaprost T $5 \mathrm{ml} \mathrm{i.m.}$ & Enzaprost T $5 \mathrm{ml}$ i.m. \\
\hline Day 10 & Ovarelin $2 \mathrm{ml}$ i.m. & Ovarelin $2 \mathrm{ml}$ i.m. & Ovarelin $2 \mathrm{ml}$ i.m. & Ovarelin $2 \mathrm{ml}$ i.m. \\
\hline Day 11 & $\begin{array}{l}\text { Blind Artificial in- } \\
\text { semination }\end{array}$ & $\begin{array}{l}\text { Blind Artificial in- } \\
\text { semination }\end{array}$ & $\begin{array}{l}\text { Blind Artificial } \\
\text { insemination }\end{array}$ & $\begin{array}{l}\text { Blind Artificial insemi- } \\
\text { nation }\end{array}$ \\
\hline Day 12 & Blood sampling & Blood sampling & Blood sampling & Blood sampling \\
\hline Day 55 & $\begin{array}{l}\text { ultrasound gestation } \\
\text { diagnosis }\end{array}$ & $\begin{array}{l}\text { ultrasound gestation } \\
\text { diagnosis }\end{array}$ & $\begin{array}{l}\text { ultrasound gestation } \\
\text { diagnosis }\end{array}$ & $\begin{array}{l}\text { ultrasound gestation } \\
\text { diagnosis }\end{array}$ \\
\hline
\end{tabular}


Животноводство и кормопроизводство 2021 / Animal Husbandry and Fodder Production 2021;104(4) 34 БИОЭЛЕМЕНТОЛОГИЯ В ЖИВОТНОВОДСТВЕ И РАСТЕНИЕВОДСТВЕ/ BIOELEMENTOLOGY IN ANIMAL HUSBANDRY AND CROP PRODUCTION

The products used in the protocol were: Ovarelin $50 \mu \mathrm{g} / \mathrm{ml}(\mathrm{GnRH})$, Ceva Sante Animle, France; Enzaprost T 5mg/ml (PGF2 $\alpha$ ), Ceva Sante Animle, France; Sel-E-Vit (containing: sodium slenite $0,5 \mathrm{mg} / \mathrm{ml}$ and Vitamin E $50 \mathrm{mg} / \mathrm{ml}$ ), Pasteur Bucharest, Romania; Mineral TS (containing: iron $2.9 \mathrm{~g}$, manganese $2.4 \mathrm{~g}$, copper $1.1 \mathrm{~g}$ and zinc $2.6 \mathrm{~g}$ ), Laboratoires Biove, France.

The blood was collected into clot activator BD Vacutainer and centrifuged for $10 \mathrm{~min}$ at $3000 \times \mathrm{g}$ to obtain the serum for the bio-elements analysis.

The levels of the main bioelements such as manganese (Mn), selenium (Se), zinc $(\mathrm{Zn})$, copper $(\mathrm{Cu})$, and iron $(\mathrm{Fe})$ in serum were assessed by atomic absorption spectroscopy (AAS) using a ContrAA800 spectrophotometer (Analytic Jena, Germany) using a furnace with pyrolitic tube for Mn, Se and $\mathrm{Cu}$, and flame analisys for $\mathrm{Zn}$ and $\mathrm{Fe}$.

Samples preparation for AAS analyses were performed by microwave digestion (Multiwave GO, Anton Paar, $\mathrm{GmbH}$, Austria), adding $10 \mathrm{~mL}$ of concentrated nitric acid and $2 \mathrm{~mL}$ of hydrogen peroxide over $1 \mathrm{~g}$ of sample with the parameter set as $120^{\circ} \mathrm{C}, 800 \mathrm{~W}$ for $20 \mathrm{~min}$. All used reagents were a highpurity grade (Suprapur Merk, Germany) and the calibration standards were prepared from a Merck CertiPur ICP $1000 \mathrm{mg} / \mathrm{L}$ stock standard solution.

For the gestation diagnosis was used the portable BCS Easi-Scan:Go (IMV Imaging, UK) ultrasound scaner.

The obtained results were expressed as mean \pm SEM by one-way ANOVA with the Bonferroni correction considering the differences are statistically provided when $\mathrm{P} \leq 0.05$ or lower. The software used was GraphPad Prism 6.0 for Windows (GraphPad Software, San Diego, USA).

\section{Results and discussions.}

Some of the bioelements such as $\mathrm{Cu}, \mathrm{Zn}, \mathrm{Mn}, \mathrm{Fe}$ and $\mathrm{Se}$ act as co-factors for multiple anti-oxidant enzymes (Méplan C, 2011) and are involved in many metabolic processes in living organisms, being essential for cell metabolism and many other body functions, including energy production, growth, reproduction and the nervous system.

As is presented in Figure 1, in our study we observed that in the day 0 the levels of Se were not significant $(\mathrm{P} \geq 0.05)$ in all groups. In the day 12 this levels were increased, in group E1 comparative to control $(+26.59 \%)$, but the differences were statisticaly not significant $(\mathrm{P} \geq 0.05)$, and highly significant in $\mathrm{E} 2$ and $\mathrm{E} 3$ groups comparative to control (E2 $+47.57 \%, \mathrm{P} \geq 0.001$; $\mathrm{E} 3+40.73 \%, \mathrm{P} \geq 0.01$ ). Se levels were increased in day 12 comparative to day 0 , significantly only for E2 amd E3 (E1 $+15.96 \%$; E2 $+36.41 \%$, $\mathrm{P} \geq 0.05 ; \mathrm{E} 3+36.02 \%)$. There were not significant differences between experimental groups regarding te selenium levels, evan if was observed a slight increase in E2 and E3 groups in the day 12 (E2/E1: $+16.56 \%$, E3/E1: $+11.16 \%$, E3/E2: $-4.62 \%)$.

The $\mathrm{Cu}$ levels in day 0 was not significantly $(\mathrm{P} \geq 0.05)$ different in experimental groups comparative to control, the same sittuation being obseved in the day 12, exception being in group E2, where was observed a slight, but significant $(\mathrm{P} \leq 0.05)$ increase comparative to control $(+8.27 \%)$. There were recorded also differences regarding the $\mathrm{Cu}$ levels in groups that received supplemeent whit Mineral TS comparative to the group that received only Se and vit.E (E2/E1: $+9.45 \%, \mathrm{P} \leq 0.01)$, the level being decreased in group that received both supplements (E3/E2: $-8.56 \%)$.

In the day 0 , the $\mathrm{Zn}$ level prezented slight and not significant $(\mathrm{P} \geq 0.05)$ fluctuations in experimental groups comparative to control group. The situation was different in the day 12, all experimental groups recorded highly significant $(\mathrm{P} \leq 0.001)$ decrease of $\mathrm{Zn}$ comparative to control $(\mathrm{E} 1 / \mathrm{C}$ : $26.72 \%$, E2/C: $-19,13 \%$, E3/C: $-26.71 \%$ ) and comparative to day 0 (E1: $-31.15 \%$, E2: $-21.29 \%$, E3: $25.15 \%)$.

The Mn levels presented not significantly $(\mathrm{P} \geq 0.05)$ levels in experimental groups comparative to control. Even if in the day 12 were recorded decreases of $\mathrm{Mn}$ in experimental groups comparative to control (E1/C: $-13.25 \%$, E2/C: $-27.88 \%$, E3/C: $-34.62 \%$ ), and especially, comparative to day 0 (E1: 18.73\%, E2: $-35.74 \%$, E3: $-29.03 \%)$, these decreases were statistically not significant ( $\mathrm{P} \geq 0.05)$. 

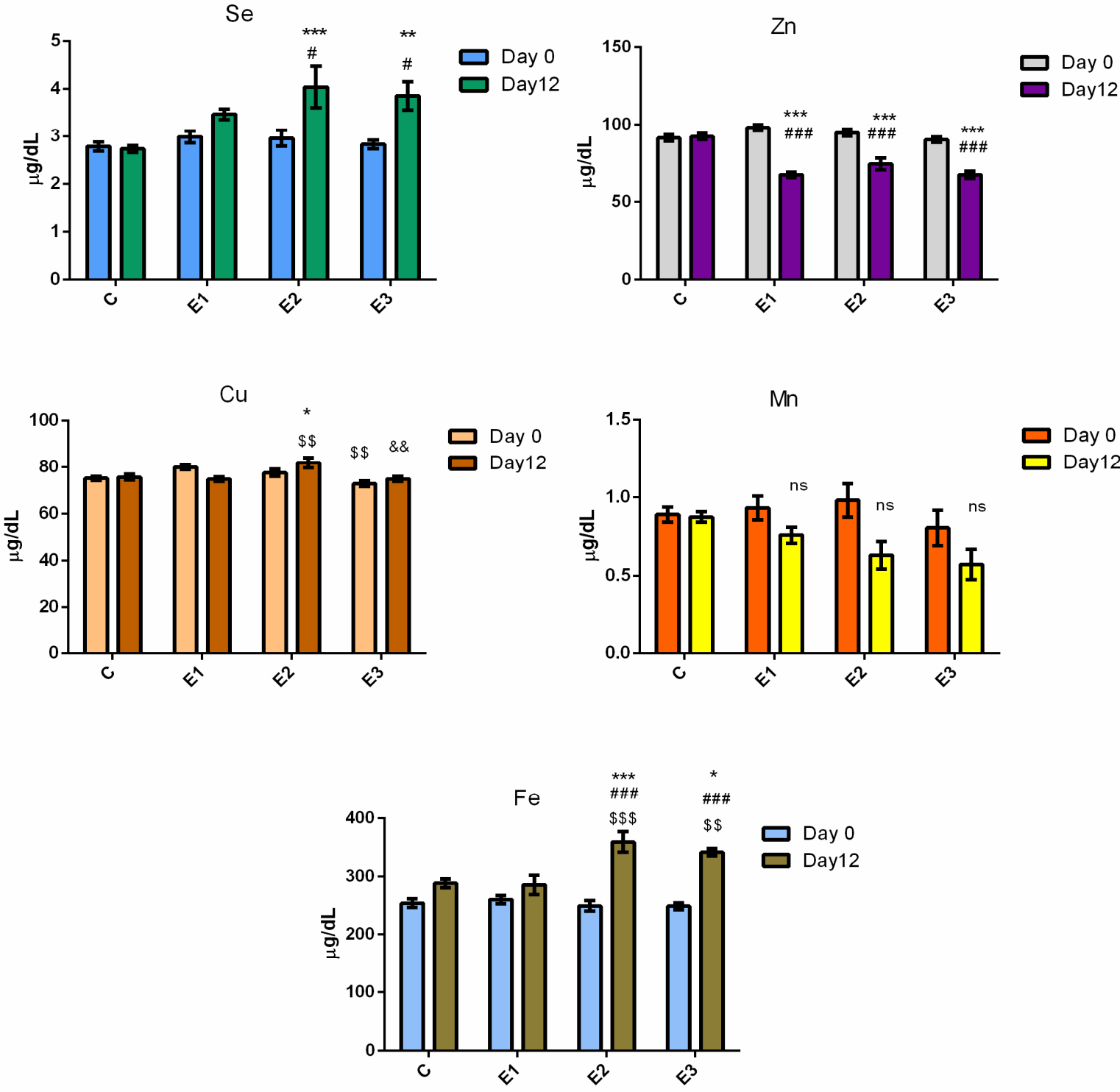

Figure 1 - Levels of selected bio-elements in cattle with normal fertility protocol and Mineral TS Comparative to $\mathrm{C}$ group: * $-\mathrm{P} \leq 0.05, * *-\mathrm{P} \leq 0.01, * * *-\mathrm{P} \leq 0.001$

Comparative between experimental groups: ns - not significant Comparative between Day 0 and Day 12: \# $-\mathrm{P} \leq 0.05$, \#\# - P $\leq 0.01$ Comparative to $\mathrm{E} 1$ group: $\$ \$-\mathrm{P} \leq 0.01, \$ \$ \$-\mathrm{P} \leq 0.001$

Comparative to E2 group: \&\& $-\mathrm{P} \leq 0.01$

Regarding the Fe levels, in the day 0 were recorded not significant $(\mathrm{P} \geq 0.05)$ between control and experimental groups. The situation was changed in the day 12 in groups that received mineral supplementation comparative to control. There was recorded a significant increase of Fe level in groups that received Mineral TS comparative to control $(\mathrm{E} 2 / \mathrm{C}:+24.63 \%, \mathrm{P} \leq 0.001 ; \mathrm{E} 3 / \mathrm{C}:+18.49 \%, \mathrm{P} \leq 0.05)$ and comparative to group that received Se+Vit E (E2/E1: $+25.81 \%, \mathrm{P} \leq 0.001$; E3/E1: $+19.61 \%, \mathrm{P} \leq 0.01)$. For 
Животноводство и кормопроизводство 2021 / Animal Husbandry and Fodder Production 2021;104(4) 36 БИОЭЛЕМЕНТОЛОГИЯ В ЖИВОТНОВОДСТВЕ И РАСТЕНИЕВОДСТВЕ/ BIOELEMENTOLOGY IN ANIMAL HUSBANDRY AND CROP PRODUCTION

this groups the differences in the day 12 was significantly $(\mathrm{P} \leq 0.001)$ higher than in day 0 (E2: $+44.19 \%$, E3: $+37.47 \%$ ).

In the Figure 2 is presented the fertility percentage in cattles supplemented with Mineral TS comparative to normal protocol. We recorded an increase of conception rate in all groups that received supplements comparative to control that received the notmal fertility protocol $(\mathrm{E} 1 / \mathrm{C}:+28.78 \%$, E2/C: $+22.72 \%, \mathrm{E} 3 / \mathrm{C}:+13.64 \%)$.

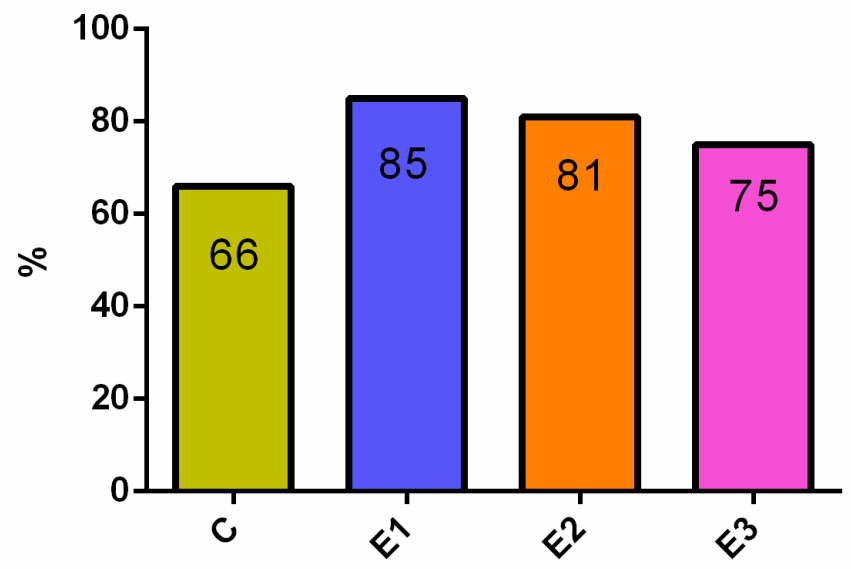

Figure 2 - The fertility percentage in cattle supplemented with Mineral TS or/and Se+Vit.E vs control

Supplementation with well known Se and Vit.E was the most potent supplement to increase fertility percentage, but supplementation with Mineral TS proves to be a encouraging possibility offering almost the same results as classic supplementation with Se and Vit.E, being only with a few percentages under (E2/E1: $-4.70 \%$ ). Combining the both supplements proves to be less efficient regarding the fertility percentage that if there will be administered separately (E3/E1: $-11.76 \%, \mathrm{E} 3 / \mathrm{E} 2:-7.40 \%)$.

The potential for minerals to play a significant role in herd fertility is indisputable, the mineral elements that are of particular importance are categorized into major and trace elements such as: iron, iodine, copper, manganese, zinc, cobalt, molybdenum and selenium (Boland MP, 2003).

Copper and selenium concentrations are relatively low in local forage, and are typically supplemented by farmers, therefore, animals living outside on local forage and not supplemented with these trace elements are estimated to be relatively low in both copper and selenium (Van den Top AM, 2005).

Interactions between $\mathrm{Cu}$ and $\mathrm{Zn}$ within the intestinal tract are important for the amount absorbed of these elements, because increased concentrations of $\mathrm{Zn}$ can induce the synthesis of thionein, this protein binds $\mathrm{Zn}$ or $\mathrm{Cu}$, thereby forming metallothionein (Cousins RJ, 1985), but it is still not clear as to what extent $\mathrm{Zn}$-induced metallothionein formation can influence $\mathrm{Cu}$ absorption from the intestine in ruminants (Van den Top AM, 2005).

Grace ND et al., 2001 and 2012, noted an increase blood concentration of Se and $\mathrm{Cu}$ in cows that received supplements prior to mating which is in accordance with our findings in cattle.

Goselink RMA and Jongbloed AW, 2012 presented different studies regarding the influence of minerals supplementation on cow's fertility, some of them presenting positive results which are in accordance with our findings and other disagreed the idea that mineral administration has a positive effect.

Moeini MM et al., 2003, obtained the increase of conception rate and increase of blood $\mathrm{Cu}$ levels

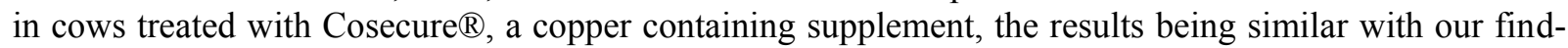
ings. 
Животноводство и кормопроизводство 2021 / Animal Husbandry and Fodder Production 2021;104(4)

БИОЭЛЕМЕНТОЛОГИЯ В ЖИВОТНОВОДСТВЕ И РАСТЕНИЕВОДСТВЕ/

BIOELEMENTOLOGY IN ANIMAL HUSBANDRY AND CROP PRODUCTION

\section{Conclusion.}

Administration of supplements with minerals was followed by changes in the serum levels of cattle, especially the increase of $\mathrm{Se}, \mathrm{Cu}$ and $\mathrm{Fe}$, decrease of $\mathrm{Zn}$ and $\mathrm{Mn}$ and was followed by the increased conception rate.

We can conclude that introduction of minerals, e.g. Mineral TS, in the fertilization protocol in cattle could have good effects with lower costs and less work.

Further studies whith a longer period and another way of administration are nessesary to be performed for a better optimization of the fertility protocol in cattle.

\section{References}

1. Boland MP. Trace minerals in production and reproduction in dairy cows. Advances in Dairy Technology. 2003;15:319-330.

2. Cousins RJ. Absorption, transport, and hepatic metabolism of copper and zinc: special reference to metallothionein and ceruloplasmin. Physiological Reviews. 1985;65(2):238-309. doi: 10.1152/physrev.1985.65.2.238

3. Crowe MA, Hostens M, Opsomer G. Reproductive management in dairy cows - the future. Ir Vet J. 2018;71:1 doi:10.1186/s13620-017-0112-y

4. EUR-Lex. Access to European Union Law [Internet]. Directive 2010/63/EU of the European Parliament and of the Council of 22 September 2010 on the protection of animals used for scientific purposes. Available from: https://eur-lex.europa.eu/LexUriServ/LexUriServ.do?uri=OJ:L:2010:276: 0033:0079:en:PDF

5. Goselink RMA, Jongbloed AW. Zinc and copper in dairy cattle feeding. Report 519. Wageningen UR Livestock Research; 2012:18 p.

6. Grace ND, Ankenbauer-Perkins KL, Alexander AM, Marchant RM. Relationship between blood selenium concentration or glutathione peroxidase activity, and milk selenium concentrations in New Zealand dairy cows. N Z Vet J. 2001;49(1):24-28. doi: 10.1080/00480169.2001.36198

7. Grace ND, Knowles SO. Trace element supplementation of livestock in new zealand: meeting the challenges of free-range grazing systems. Vet Med Int. 2012;2012:639472. doi: 10.1155/2012/639472

8. Hurley WL, Doane RM. Recent developments in the roles of vitamins and minerals in reproduction. J Dairy Sci. 1989;72(3):784-804. doi: 10.3168/jds.S0022-0302(89)79170-0

9. León-Cruz M, Ramirez-Bribiesca E, Lopez-Arellano R, Miranda-Jiménez L, Rodríguez-Patino G, Díaz-Sánchez V, Revilla-Vázquez A. Trace mineral controlled-release intraruminal boluses. Review. Revista Mexicana de Ciencias Pecuarias. 2020;11(2):498-516. doi:10.22319/rmcp.v11i2.5349

10. Mackenzie AM, Moeini MM, Telfer SB. The effect of a copper, cobalt and selenium bolus on fertility and trace element status of dairy cattle. BSAP Occasional Publication. 2001;26(2)423-427. doi: $10.1017 / \mathrm{S} 0263967 \mathrm{X} 00034030$

11. McDowell LR, Arthington JD. Minerals for grazing ruminants in tropical regions. 4th ed. USA: University of Florida, Centre for Tropical Agriculture; 2005:86 p.

12. Méplan C. Trace elements and ageing, a genomic perspective using selenium as an example. $\mathrm{J}$ Trace Elem Res Med Biol. 2011;1:11-16. doi: https://doi.org/10.1016/j.jtemb.2010.10.002

13. Moeini MM, Telfer SB, Sanjabi MR. The effect of cosecure ${ }^{\circledR}$ supplementation on the copper status and fertility of grazing holstein - friesian dairy cattle. Acta Vet Scand. 2003;44:80. doi:10.1186/1751-0147-44-S1-P80

14. Nielsen FH. Trace elements. Book Chapter. In: Katz SH, Weaver WW, editors. Encyclopedia of food and culture. NY: Charles Scribner's Sons; 2003:410-415.

15. Van den Top AM. Reviews on the mineral provision in ruminants (IX): copper metabolism and requirements in ruminants. ND: CVB. 2005;41:61 p. 
Животноводство и кормопроизводство 2021 / Animal Husbandry and Fodder Production 2021;104(4)

Information about the authors:

George Vlad Goilean, PhD student, Department of Toxicology, Faculty of Veterinary Medicine, Banat`s University of Agricultural Sciences and Veterinary Medicine "King Michel I of Romania" from Timisoara, 300645, Timisoara, Romania, Calea Aradului 119.

Teodor Romeo Cristina, PhD, DVM, Professor, Head of Department of Toxicology, Faculty of Veterinary Medicine, Banat's University of Agricultural Sciences and Veterinary Medicine "King Michel I of Romania” from Timisoara, 300645, Timisoara, Romania, Calea Aradului 119.

Alexandru Octavian Doma, PhD, DVM, Assistant Professor, Faculty of Veterinary Medicine, Banat's University of Agricultural Sciences and Veterinary Medicine "King Michel I of Romania" from Timisoara, 300645, Timisoara, Romania, Calea Aradului 119.

Eugenia Dumitrescu, PhD, DVM, Associate Professor, Departments of Pharmacology and Pharmacy, Faculty of Veterinary Medicine, Banat's University of Agricultural Sciences and Veterinary Medicine "King Michel I of Romania" from Timisoara, 300645, Timisoara, Romania, Calea Aradului 119

Alexandru Eugeniu Mizeranschi, Researcher, Research and Development Station for Bovine 310059, Arad, Romania, Bodogului 32.

Razvan Florin Moruzi, PhD student, Departments of Pharmacology and Pharmacy, Faculty of Veterinary Medicine, Banat's University of Agricultural Sciences and Veterinary Medicine "King Michel I of Romania" from Timisoara, 300645, Timisoara, Romania, Calea Aradului 119.

Diana Maria Degi, Departments of Toxicology, Faculty of Veterinary Medicine, Banat`s University of Agricultural Sciences and Veterinary Medicine "King Michel I of Romania" from Timisoara, 300645, Timisoara, Romania, Calea Aradului 119.

Sergiu Alic Orasan, Departments of Pharmacology and Pharmacy, Faculty of Veterinary Medicine, Banat's University of Agricultural Sciences and Veterinary Medicine "King Michel I of Romania" from Timisoara, 300645, Timisoara, Romania, Calea Aradului 119.

Radu Ionel Neamț, Researcher, Research and Development Station for Bovine, 310059, Arad, Romania, Bodogului 32.

Florin Muselin, PhD, DVM, MS, Associate Professor, Department of Toxicology, Faculty of Veterinary Medicine, Banat's University of Agricultural Sciences and Veterinary Medicine "King Michel I of Romania" from Timisoara, 300645, Timisoara, Romania, Calea Aradului 119; Romanian AcademyBranch Timisoara, 300223, Timişoara, România, Bv. Mihai Viteazu 24.

The article was submitted 06.09.2021; approved after reviewing 13.09.2021; accepted for publication 13.12.2021 